\title{
Atiprimod blocks STAT3 phosphorylation and induces apoptosis in multiple myeloma cells
}

\author{
M Amit-Vazina', S Shishodia', D Harris', Q Van', M Wang', D Weber'2, R Alexanian'2, M Talpaz', BB Aggarwal' \\ and Z Estrov*,
}

'Department of Bioimmunotherapy, The University of Texas M.D. Anderson Cancer Center, Houston, TX, USA; ${ }^{2}$ Department LymphomalMyeloma, The University of Texas M.D. Anderson Cancer Center, Houston, TX, USA

Multiple myeloma (MM) accounts for I \% of all cancer deaths. Although treated aggressively, almost all myelomas eventually recur and become resistant to treatment. Atiprimod (2-(3-Diethylaminopropyl)-8,8-dipropyl-2-azaspiro[4,5] decane dimaleate) has exerted anti-inflammatory activities and inhibited oeteoclast-induced bone resorption in animal models and been well tolerated in patients with rheumatoid arthritis in phase I clinical trials. Therefore, we investigated its activity in MM cells and its mechanism of action. We found that Atiprimod inhibited proliferation of the myeloma cell lines U266-BI, OCI-MY5, MM-I, and MM-IR in a timeand dose-dependent manner. Atiprimod blocked U266-BI myeloma cells in the $\mathrm{G}_{0} / \mathrm{G}_{1}$ phase, preventing cell cycle progression. Furthermore, Atiprimod inhibited signal transducer and activator of transcription (STAT) 3 activation, blocking the signalling pathway of interleukin-6, which contributes to myeloma cell proliferation and survival, and downregulated the antiapoptotic proteins Bcl-2, $\mathrm{Bcl}-\mathrm{X}_{\mathrm{L}}$, and $\mathrm{Mcl}-\mathrm{I}$. Incubation of U266-BI myeloma cells with Atiprimod induced apoptosis through the activation of caspase 3 and subsequent cleavage of the DNA repair enzyme poly(adenosine diphosphate-ribose) polymerase. Finally, Atiprimod suppressed myeloma colony-forming cell proliferation in fresh marrow cells from five patients with newly diagnosed MM in a dose-dependent fashion. These data suggest that Atiprimod has a role in future therapies for MM.

British Journal of Cancer (2005) 93, 70-80. doi:I0.1038/sj.bjc.6602637 www.bjcancer.com

Published online 2I June 2005

(c) 2005 Cancer Research UK

Keywords: multiple myeloma; signal transduction; clonogenic assay; nuclear factor $\kappa \mathrm{B}$, apoptosis

Multiple myeloma (MM) is a clonal B-cell neoplasm characterised by an accumulation of neoplastic plasma cells. Multiple myeloma accounts for $1 \%$ of all cancer deaths and affects approximately 14500 Americans each year (Jemal et al, 2003). For many years, intermittent courses of melphalan and prednisone constituted the standard therapy for MM. Several other drugs, including alkylating agents, vinca alkaloids, and, in recent years, thalidomide and its derivatives, and the proteasome inhibitor bortezomib, have been studied with various degrees of success (Dimopoulos et al, 2003; Anderson, 2004). However, almost all myelomas eventually recur and become resistant to treatment (Dimopoulos et al, 2003). Thus, the search for more effective agents continues.

Several studies have demonstrated that of all B-cell-stimulating factors, interleukin (IL)-6 plays the most important role in MM by regulating the growth and survival of the neoplastic cells (Kawano et al, 1988; Klein et al, 1995; Cote et al, 2002). Interleukin-6 has been implicated in the pathogenesis of MM (Klein et al, 1995). This cytokine, which is produced by both myeloma and bone marrow (BM) stroma cells, stimulates MM cell proliferation in an autocrine and paracrine fashion (Klein et al, 1995; Chauhan et al, 1996),

* Correspondence: Dr Z Estrov, Department of Leukemia, Unit 428, The University of Texas M.D. Anderson Cancer Center, 15I5 Holcombe Blvd., Houston, TX 77030, USA; E-mail: zestrov@mdanderson.org Revised 8 April 2005; accepted 2 May 2005; published online 21 June 2005 augments osteoclast activity (Szczepek et al, 2001), and provides the neoplastic cells with a survival advantage (Lichtenstein et al, 1995). Indeed, serum IL-6 levels in patients with MM have been shown to be correlated with disease stage, activity, and survival (Klein et al, 1990). Thus, the inhibition of IL-6 activity may be an adequate strategy for suppressing MM cells.

Atiprimod (SK\&F 106615; Callisto Pharmaceuticals, New York, NY, USA) is an azaspirane, a cationic amphiphilic compound, with anti-inflammatory activity. Several azaspiranes have been found to be beneficial in animal models of adjuvant induced arthritis (Bradbeer et al, 1996), autoimmune encephalitis (Badger et al, 1989), lupus erythematosus (Albrightson-Winslow et al, 1990), autoimmune diabetes mellitus (Rabinovitch et al, 1993), and solid organ transplantation graft rejection (Badger et al, 1991; Fan et al, 1993). Although azaspiranes have been studied extensively, their mechanism of action is not completely understood. Several mechanisms, including the upregulation of nonspecific (Badger et al, 1990a, b) and splenic (Badger et al, 1990a, b; Schmidbauer et al, 1993) suppressor cell activity and downregulation of various cytokine receptors (e.g. IL-2 receptor, transferrin receptor), adhesion molecules (e.g., ICAM-1), and cytokines (e.g. IL-2, interferon- $\gamma$, IL-1, tumour necrosis factor- $\alpha$, and IL-6) have been reported (Schmidbauer et al, 1993). These mechanisms and the ability of azaspiranes to normalise bone mineral density, prevent structural damage to joints and periarticular bone, and downregulate serum IL-6 levels (Bradbeer et al, 1996) without inducing 
myelotoxicity (King et al, 1991) suggest that these compounds may be effective against autoimmune disorders and diseases causing bone destruction. Therefore, Atiprimod was administered to patients with rheumatoid arthritis in phase I clinical trials and found to be well tolerated.

Owing to Atiprimod's broad array or activities, we speculated that Atiprimod would inhibit MM cells by suppressing the activity of IL-6. We found that Atiprimod blocked the activation of the signal transducer and activator of transcription (STAT) 3, inhibited myeloma cell proliferation, and induced cell cycle arrest and apoptosis in MM cells.

\section{MATERIALS AND METHODS}

\section{Patients}

Bone marrow (BM) aspirates were obtained from five patients with newly diagnosed MM (Table 1). All studies were performed with the patients' informed consent and were approved by the Institutional Review Board at The University of Texas M.D. Anderson Cancer Center, Houston, TX, USA.

\section{Cell lines}

The MM cell lines MM-1, U266-B1, and RPMI-8226 were obtained from the American Type Culture Collection (ATCC; Rockville, $\mathrm{MD}, \mathrm{USA}$ ), MM-1R cells (a dexamethazone-resistant variant of the MM-1 line) were provided by Steven Rosen (Northwestern University Medical School, Chicago, IL, USA), and the cell line OCI-MY5 was provided by Hans Messner (Ontario Cancer Institute, Toronto, ON, Canada). MM-1, MM-1R, and U266-B1 cell lines were maintained in RPMI 1640 (Sigma Chemical Co., St Louis, MO, USA) supplemented with $10 \%$ fetal calf serum (FCS; Hyclone, Logan, UT, USA). OCI-MY5 cells were maintained in Iscove's modified Dulbecco's medium (IMDM) supplemented with $10 \%$ FCS. The KM102 marrow stroma cell line was established from normal BM (Harigaya and Handa, 1985) and maintained in RPMI 1640 supplemented with $10 \%$ FCS.

\section{Drug preparation}

Atiprimod (Callisto Pharmaceuticals, New York, NY, USA) was dissolved in phosphate-buffered saline (PBS; GIBCO BRL, Grand Island, NY, USA) at a final concentration of $8 \mathrm{~mm}$. The stock solution was further diluted in tissue culture medium.

\section{Enzyme-linked immunosorbent assay (ELISA)}

Enzyme-linked immunosorbent assays were performed with IL-6 and IL-6 receptor (IL-6R) ELISA kits (Biosource International, Camarillo, CA, USA). In one experiment, U266-B1 cells were harvested at the logarithmic phase of their growth, washed twice in RPMI 1640, and incubated in RPMI 1640 supplemented with $10 \%$ FCS at $37^{\circ} \mathrm{C}$ with or without $2 \mu \mathrm{m}$ Atiprimod. Supernatant samples were harvested at $1,6,8$, and $16 \mathrm{~h}$ after incubation. In another experiment, myeloma cell lines were incubated for $72 \mathrm{~h}$ with or without either normal marrow stroma or KM102 stroma cells in the presence or absence of Atiprimod. Supernatant samples were harvested and both IL- 6 and soluble IL-6R levels were analysed in accordance with the manufacturer's instructions. Briefly, supernatant samples were added to the wells in duplicate and incubated for $2 \mathrm{~h}$ at $37^{\circ} \mathrm{C}$. The test wells were then washed three times in PBS, incubated with rabbit IL- 6 antiserum for $2 \mathrm{~h}$, washed as previously described, and incubated for $30 \mathrm{~min}$ with goat anti-rabbit IgG conjugated to horseradish peroxidase. The test wells were vigorously washed, a substrate, provided by the manufacturer, was added, and the colour intensity was read within $15 \mathrm{~min}$ at a wavelength of $490 \mathrm{~nm}$ with a microplate reader.

\section{Electrophoretic mobility shift assay for analysis of NF- $\kappa$ B activation}

NF- $\kappa$ B activation was analysed by electrophoretic mobility gel shift assay (EMSA) as described previously (Chaturvedi et al, 2000). In brief, $8-\mu \mathrm{g}$ nuclear extracts prepared from treated or untreated $\mathrm{U} 266-\mathrm{B} 1$ cells were incubated with a ${ }^{32} \mathrm{P}$-end-labelled $45-\mathrm{mer}$ double-stranded NF- $\kappa \mathrm{B}$ oligonucleotide from the human immunodeficiency virus-1 long terminal repeat $\left(5^{\prime}\right.$-TTGTTACAAGG GACTTTCCGCT GGGGACTTTCCAG GGAGGCGTGG- $3^{\prime}$ ) $\overline{\text { for }}$ $15 \mathrm{~min}$ at $37^{\circ} \mathrm{C}$, and the DNA-protein complex was resolved on a $6.6 \%$ native polyacrylamide gel. The radioactive bands from the dried gels were visualised and quantitated by a PhosphorImager (Molecular Dynamics, Sunnyvale, CA, USA) with the ImageQuant software program.

\section{Western immunoblotting}

Cell lysates were assayed for their protein concentration using the BCA protein assay reagent (Pierce Chemical, Rockford, IL, USA). Each set of paired lysate samples was then adjusted to have the same protein concentration. Sodium dodecyl sulphatepolyacrylamide gel electrophoresis (SDS-PAGE) (Laemmli, 1970) was conducted at constant wattage $(10 \mathrm{~W})$ in running buffer cooled to $4{ }^{\circ} \mathrm{C}$. Stacking gels contained $4 \%\left(\mathrm{wt} \mathrm{vol}^{-1}\right)$ acrylamide, and separating gels contained $12 \%$ (wt/vol) acrylamide. Approximately $50 \mu \mathrm{g}$ of sample protein was loaded into each lane. Proteins separated with SDS-PAGE were transferred to nitrocellulose membranes; the transfers were performed overnight at $30 \mathrm{~V}$ in a cooled $\left(4^{\circ} \mathrm{C}\right)$ reservoir containing $25 \mathrm{~mm}$ Tris (tris (hydroxymethyl) aminomethane), $192 \mathrm{~mm}$ glycine, and $20 \%$ methanol (pH 8.3) (Towbin et al, 1979) transfer buffer. The nitrocellulose membranes were then removed from the blot apparatus and placed in a solution of Ponceau S stain $(0.5 \%$ Ponceau S and $1 \%$ glacial acetic acid in water) to verify equal loading of protein in the control and treated samples (Gershoni and Palade, 1983).

After membranes were stained for $5 \mathrm{~min}$, they were rinsed for $2 \mathrm{~min}$ and examined. Equal loading of protein was verified, and the membranes were then rinsed for an additional $10 \mathrm{~min}$ and immunoscreened. The membranes were blocked with BLOTTO (5\% dried milk dissolved in $50 \mathrm{ml}$ of PBS) for at least $1 \mathrm{~h}$ at room

Table I Clinical data on MM patients

\begin{tabular}{|c|c|c|c|c|c|c|c|c|}
\hline Patient & Age/sex & MM Type & $\mathrm{Hb}\left(\mathrm{g} \mathrm{dl}^{-1}\right)$ & $\begin{array}{c}\text { WBC } \\
\left(\times 10^{9} 1^{-1}\right)\end{array}$ & $\begin{array}{l}\text { Platelets } \\
\left(\times 10^{9} I^{-1}\right)\end{array}$ & $\begin{array}{c}\% \text { BM } \\
\text { myeloma cells }\end{array}$ & $\begin{array}{c}\text { Serum paraprotein } \\
\left(\mathrm{g} \mathrm{dl}^{-1}\right)\end{array}$ & $\begin{array}{c}\text { Urine paraprotein } \\
\left(\mathrm{g}^{2} 24 \mathrm{~h}^{-1}\right)\end{array}$ \\
\hline I & $44 / F$ & $\lg G$ & 9.4 & 10.3 & 322 & 55 & 6.1 & 1.0 \\
\hline 2 & $48 / F$ & $\lg A$ & 6.9 & 6.0 & 45 & 70 & 3.5 & 0.4 \\
\hline 3 & $56 / M$ & $\lg G$ & 12.4 & 5.9 & 254 & 36 & 3.4 & 0.16 \\
\hline 4 & $48 / M$ & $\lg G$ & 10.1 & 13.2 & 231 & 58 & 6.8 & 1.2 \\
\hline 5 & $59 / M$ & $\lg A$ & 12.5 & 4.8 & 181 & 44 & 3.4 & 0.1 \\
\hline
\end{tabular}

$\mathrm{F}=$ female; $\mathrm{M}=$ male; $\mathrm{MM}=$ multiple myeloma; $\mathrm{Hb}=$ haemoglobin; $\mathrm{WBC}=$ white blood cells; $\mathrm{BM}=$ bone marrow. 
temperature. They were then washed three times in PBS plus $0.5 \%$ Tween 20. Next, the membranes were incubated for 1 to $12 \mathrm{~h}$ with the appropriate antibodies. After incubation, the membranes were rinsed three times in PBS containing 0.5\% Tween 20 for $15 \mathrm{~min}$ each. The bound antibody was detected with the ECL Western blotting detection system (Amersham, Arlington Heights, IL, USA). The membranes were incubated with an anti-rabbit and anti-mouse horseradish peroxidase-labelled antibody at a concentration of $1: 200$ and $1: 1750$, respectively, in PBS plus $0.5 \%$ Tween 20 at room temperature for $1 \mathrm{~h}$. After this incubation, the membranes were washed in PBS containing 0.5\% Tween 20, and bound antibody was detected using the ECL protocol. Chemiluminescence of the membranes was detected with X-OMAT AR5 X-ray film (Kodak, Rochester, NY, USA) in stainless steel exposure cassettes (Sigma).

The following antibodies were used: monoclonal mouse antihuman CPP32 (Trasduction Laboratories, Lexington, KY, USA) for detection of procaspase 3, rabbit anti-human cleaved caspase 3 (New England Bio Labs, Beverly, MA, USA), mouse anti-human poly(ADP-ribose) polymerase (PARP; Pharmingen, San Diego, CA, USA), mouse anti-human Bcl-2 (Transduction Laboratories, Lesington, $\mathrm{KY}, \mathrm{USA}$ ), rabbit anti-human $\mathrm{Bcl}-\mathrm{X}_{\mathrm{L}}$ (Transduction Laboratories), mouse anti-human Mcl-1 (Pharmingen), and mouse anti-human STAT3 and pSTAT3 antibodies (Upstate Cell Signaling Solutions, Charlottesville, VA, USA). Normal mouse immunoglobulin G (IgG) and rabbit IgG (Sigma) were used as controls. To confirm the detection of these proteins, we used lysates of Jurkat cells (ATCC) for the detection of procaspase 3, PARP, STAT3, pSTAT3, and Bcl-2; Hela cells (ATCC) for the detection of cleaved caspase 3; and human endothelial cells for the detection of $\mathrm{Bcl}-\mathrm{X}_{\mathrm{L}}$.

\section{Electrophoretic mobility shift assay for STAT3-DNA binding}

The STAT3-DNA binding was analysed by EMSA using a ${ }^{32} \mathrm{P}$ labelled high-affinity sis-inducible element (hSIE) probe as previously described (Yu et al, 1995). Briefly, $2 \times 10^{6}$ U266-B1 cells were incubated with $8 \mu \mathrm{m}$ Atiprimod for $0.5,1,2,4$, and $8 \mathrm{~h}$. Nuclear extracts were prepared and labelled with hSIE probe (5'-CTTCATTTCCCGTAAATCCCTAAAGCT- $3^{\prime}$ and $5^{\prime}$-AGCTTTA GGGATTTACGGGAAATGA-3'), and STAT3-DNA binding was analysed using EMSA as described above.

\section{MTT assay}

The 3,(4,5-dimethylthiazol-2-yl)-5-(3-carboxymethoxyphenyl)-2(4-sulfophenyl)-2H-tetrazolium (MTT) assay was performed using an MTT-based cell proliferation/cytotoxicity assay system (Promega, Madison, WI, USA). Briefly, U266-B1, MM-1, MM-1R, OCI-MY5, and RPMI-8266 cells were harvested at the logarithmic phase of their growth and fresh low-density MM marrow cells (containing $>40 \%$ myeloma cells) were isolated by gradient centrifugation. They were then washed twice in RPMI 1640 containing $10 \%$ FCS and counted in a hemocytometer, and their viability was determined using $0.1 \%$ trypan blue staining. Equal numbers of viable cells $\left(5 \times 10^{4}\right.$ cells per well) were incubated in a total volume of $100 \mu \mathrm{l}$ of RPMI 1640 medium supplemented with $10 \%$ FCS alone or with Atiprimod at increasing concentrations; the incubations were continued for $72 \mathrm{~h}$ in 96 -well flat-bottomed plates (Linbro; Flow Laboratories, McLean, VA, USA) at $37^{\circ} \mathrm{C}$ in a humidified $5 \% \mathrm{CO}_{2}$ atmosphere. In another experiment, the cells were incubated for 24, 48, and $72 \mathrm{~h}$. After incubation, $20 \mu \mathrm{l}$ of CellTiter96 One Solution Reagent (Promega) was added to each well. The plates were then incubated for an additional $60 \mathrm{~min}$ at $37^{\circ} \mathrm{C}$ in a humidified $5 \% \mathrm{CO}_{2}$ atmosphere. Immediately after incubation, absorbance was read using a 96-well plate reader at a wavelength of $490 \mathrm{~nm}$. Each data point was determined six times before analysis.

\section{Cell cycle analysis}

Cell cycle analysis was performed according to standard protocols. Briefly, $5 \times 10^{6}$ cells were pelleted after incubation with Atiprimod. The cell pellets were washed and resuspended in $2 \mathrm{ml}$ of $1 \%$ paraformaldehyde in PBS. Cells were incubated for $15 \mathrm{~min}$ at $4{ }^{\circ} \mathrm{C}$ and then washed again in PBS, resuspended in $2 \mathrm{ml}$ of absolute ethanol, and stored at $-20^{\circ} \mathrm{C}$ until staining. Next, the stored cells were washed twice in PBS, resuspended in $0.5 \mathrm{ml}$ of propidium iodide (PI) staining buffer $(50 \mu \mathrm{g} / \mathrm{ml} \mathrm{PI}$ and $10 \mathrm{mg} / \mathrm{ml}$ RNase in PBS), and then incubated for $1 \mathrm{~h}$ at room temperature in total darkness. Flow cytometric analysis was performed using a FACSCalibur flow cytometer and the CellQuest software program (Becton Dickinson Immunocytometry Systems, San Jose, CA, USA). Data analysis was performed using CellQuest and the Modfit LT V2.0 software program (Verity Software House, Topsham, ME, USA).

\section{Apoptosis assays}

To quantify the percentage of cells undergoing apoptosis, we used annexin V-CY5 (Pharmingen, San Diego, CA, USA) as previously described (Vermes et al, 1995). Briefly, Atiprimod-treated U266 cells were washed twice with cold PBS and then resuspended in binding buffer (10 nM HEPES ( $\mathrm{N}$-2-hydroxyethylpiperazine- $\mathrm{N}$-2ethanesulphonic acid), $140 \mathrm{nM} \mathrm{NaCl}$, and $5 \mathrm{nM} \mathrm{CaCl}_{2}, \mathrm{pH} \mathrm{7.4)}$ at a concentration of $1 \times 10^{6}$ cells $\mu \mathrm{l}^{-1}$. After incubation, $100 \mu \mathrm{l}$ of the solution was transferred to a $5-\mathrm{ml}$ culture tube to which $5 \mu \mathrm{l}$ of annexin V-CY5 and $10 \mu \mathrm{l}$ of PI were added. The tube was gently vortexed and incubated for $15 \mathrm{~min}$ at room temperature in total darkness. At the end of the incubation, $400 \mu \mathrm{l}$ of binding buffer was added to the tube, and the cells were analysed immediately by flow cytometry. Flow cytometric analysis was performed with a FACSCalibur flow cytometer using CellQuest. Data analysis was performed with CellQuest and Modfit LT V2.0.

To establish that Atiprimod induces apoptosis in MM cells, we used the TdT-mediated dUTP nick-end labelling (TUNEL) apoptosis detection system (Promega) as previously described (Estrov et al, 1999). Briefly, U266 cells were incubated with $6 \mu \mathrm{M}$ Atiprimod for $2 \mathrm{~h}$ in the presence or absence of a $50 \mu \mathrm{M}$ concentration of the caspase inhibitor Ac-DEVD-CHO (Thornberry et al, 1994) (CalBiochem, La Jolla, CA, USA). Formaldehydetreated cytospun cells were made permeable with $0.2 \%$ Triton X-100 in PBS. After being washed, the slides were treated with equilibration buffer (supplied with the TUNEL kit) and then incubated with TdT buffer (prepared according to the manufacturer's instructions) for $60 \mathrm{~min}$. The staining reaction was terminated by treating the slides with $2 \times$ standard sodium citrate for $15 \mathrm{~min}$. After another washing, the slides were treated with antifade solution and then mounted on slides with glass coverslips and rubber cement. The slides were analysed using a fluorescence microscope.

\section{Clonogenic assay}

A modification of a previously described clonogenic assay was used to grow MM colony-forming cells (Millar et al, 1988; Rhodes et al, 1990). Briefly, fresh, low-density BM cells from patients with MM were fractionated using immunomagnetic beads, and $1 \times 10^{5}$ CD3-, CD33-, and CD14-negative cells were cultured in $0.8 \%$ methylcellulose (Fluka Chemical, Ronkonkoma, NY, USA), containing $10 \%$ FCS and RPMI 1640 medium in $1 \%\left(\mathrm{vol} \mathrm{vol}^{-1}\right)$ phytohemagglutinin (PHA) T-cell-conditioned medium, and irradiated feeder cells obtained from the low-density fraction of normal donor peripheral blood cells exposed to $70 \mathrm{~Gy}$ of $\gamma$-irradiation, as previously described (Estrov et al, 1994). The culture mixture was placed in $35-\mathrm{mm}$ Petri dishes (Nunc, Naperville, IL, USA) in duplicate and maintained at $37^{\circ} \mathrm{C}$ with 
$5 \% \mathrm{CO}_{2}$ in air in a humidified atmosphere. Colonies, which were defined as clusters of more than 40 cells, were counted after 7 days using an inverted microscope.

To verify the neoplastic nature of the colony-forming cells, single colonies were microaspirated; the rearranged immunoglobulin $\mathrm{H}(\mathrm{IgH})$ gene in their DNA was amplified by polymerase chain reaction (PCR), and the product was directly sequenced and compared to that of the diagnostic BM DNA as previously described (Estrov et al, 1994). To avoid contamination by residual effete myeloma cells, only isolated colonies were microaspirated. The rearranged IgH gene in the DNA from the diagnostic myeloma $\mathrm{BM}$ cells and from individual colonies was amplified using a modification of a previously described method (Deane and Norton, 1990). Briefly, cells were placed in $1 \mathrm{ml}$ of QuickExtract DNA Extraction solution 1.0 (Epicentre, Madison, WI, USA) and lysed in accordance with the manufacturer's protocol. The DNA was harvested, and its concentration adjusted with nuclease-free water. Genomic DNA $(1-1.5 \mu \mathrm{g})$ was added to the reaction mixture, which contained $10 \mathrm{mM}$ dNTP (Promega), $25 \mathrm{mM} \mathrm{MgCl}_{2}$ (Proemga), $2.5 \mathrm{U}$ of Taq polymerase, Taq polymerase buffer (Promega), $50 \mathrm{pM}$ upstream and downstream primers, and nuclease-free water in a total volume of $50 \mu \mathrm{l}$. A separate tube was prepared for each of the five primers chosen from the first framework region of the coding strand of representative germline $\mathrm{V}_{\mathrm{H}}$ family members amplified together with a $\mathrm{J}_{\mathrm{H}}$ consensus primer of the IgH gene. The tubes were denaturated at $94^{\circ} \mathrm{C}$ for $5 \mathrm{~min}$ and then subjected to 35 cycles of denaturation at $90^{\circ} \mathrm{C}$ for $1 \mathrm{~min}$, annealing at $66^{\circ} \mathrm{C}$ for $2 \mathrm{~min}$, with an extension at $72^{\circ} \mathrm{C}$ for $2 \mathrm{~min}$, and a final extension at $72^{\circ} \mathrm{C}$ for $5 \mathrm{~min}$ in the Techgene Thermal Cycler (Techne Inc., Princeton, NJ, USA). A sample of the amplified DNA was electrophresed in a $2 \%$ E-Gel (Invitrogen Corp., Carlsbad, CA, USA) and visualised by UV illumination. The bands of interest were excised, and the DNA was purified using the Wizard SV Gel and PCR Clean-Up System (Promega). Next, the DNA from the bands was sequenced using a DNA sequencer (Applied Biosystems, Foster City, CA, USA). The primer for the coding strand was the appropriate $\mathrm{V}_{\mathrm{H}}$ family primer, and the noncoding strand was the $\mathrm{J}_{\mathrm{H}}$ consensus primer.

\section{RESULTS}

\section{Atiprimod suppresses IL-6 production by MM cells}

Atiprimod (Atiprimod) was found to downregulate IL-6 production (Bradbeer et al, 1996). Therefore, we asked whether Atiprimod would also inhibit the production of IL-6 in MM cells. We incubated U266-B1 cells with or without $8 \mu \mathrm{M}$ Atiprimod and measured IL-6 supernatant levels using an ELISA. Consistent with previous reports (Catlett-Falcone et al, 1999) we found that U266B1 cells produce IL-6, and that the levels of IL-6 in U266-B1 cell supernatant increased over time. Interleukin-6 supernatant levels increased from $28 \mathrm{pg} \mathrm{ml}^{-1}$ at $1 \mathrm{~h}$ after incubation to 71,60 , and $222 \mathrm{pg} \mathrm{ml}^{-1}$ at 6,8 , and $16 \mathrm{~h}$, respectively. Atiprimod attenuated IL6 supernatant levels to $23,42,53$, and $130 \mathrm{pg} \mathrm{ml}^{-1}$ at $1,6,8$, and 16 hours, respectively. Similar results were obtained when U266-B1 cells were incubated in the presence of normal stroma cells or the stroma cell line KM102 (Table 2). Thus, Atiprimod suppresses production of IL-6 by U266-B1 cells.

\section{Atiprimod blocks the activation of NF- $\kappa$ B}

Since the expression of IL- 6 is regulated by NF- $\kappa \mathrm{B}$ (Shimizu et al, 1990) and Atiprimod downregulates IL-6 production, we hypothesised that Atiprimod inhibits NF- $\kappa$ B. To test this hypothesis, we used U266-B1 cells, which constitutively express active NF- $\kappa \mathrm{B}(\mathrm{Ni}$ et al, 2001; Bharti et al, 2004) and produce IL-6 (Catlett-Falcone et al, 1999; Bharti et al, 2003). We incubated U266-B1 cells with
Table 2 IL-6 supernatant levels $\left(\mathrm{pg} \mathrm{ml}^{-\mathbf{I}}\right)$

\begin{tabular}{|c|c|c|c|c|c|c|}
\hline & \multirow[b]{2}{*}{-} & \multirow[b]{2}{*}{ Atiprimod } & \multicolumn{2}{|c|}{ + Normal stroma } & \multicolumn{2}{|r|}{ +KMIO2 } \\
\hline & & & - & Atiprimod & - & Atiprimod \\
\hline Normal stroma & 650 & 467 & & & & \\
\hline KMIO2 & 521 & 485 & & & & \\
\hline MMI & 0 & 0 & 573 & 594 & 583 & 566 \\
\hline MMIR & 0 & 0 & 572 & 524 & 271 & 294 \\
\hline U266-BI & 227 & 56 & 642 & 514 & 645 & 354 \\
\hline OCl-MY5 & 0 & 0 & 714 & 632 & 731 & 686 \\
\hline
\end{tabular}

Cells were incubated for $72 \mathrm{~h}$ with or without $3 \mu \mathrm{M}$ Atiprimod. The means of interleukin-6 (IL-6) levels from duplicate wells are depicted.

Atiprimod at increasing concentrations for $4 \mathrm{~h}$, and with $8 \mu \mathrm{m}$ for 1 , $4,6,8$, and $24 \mathrm{~h}$ and tested the NF- $\kappa \mathrm{B}$ activity in nuclear extracts. We found that $10 \mu \mathrm{m}$ but not $5 \mu \mathrm{m}$ Atiprimod inhibited constitutive NF- $\kappa \mathrm{B}$ activity, and that $8 \mu \mathrm{m}$ Atiprimod inhibited NF- $\kappa \mathrm{B}$ activity after a prolonged incubation (16 h) (Figure 1$)$.

\section{Atiprimod downregulates both IL-6-induced and constitutive STAT3 phosphorylation in MM cells}

Interleukin- 6 is produced by MM cells and promotes myeloma cell proliferation in an autocrine manner (Klein et al, 1995; Chauhan et al, 1996; Jemal et al, 2003; Anderson, 2004) through phosphorylation of the signalling protein STAT3 (Kaptein et al, 1996; Hirano et al, 2000; Chatterjee et al, 2002). As Atiprimod inhibits NF- $\kappa$ B activity and, by doing so, suppresses IL-6 production, we wondered whether Atiprimod downregulates STAT3 phosphorylation. Using U266-B1 cells, we found that Atiprimod inhibited STAT3 phosphorylation in a time- and dosedependent manner (Figure 2A). After U266-B1 cells were incubated for $4 \mathrm{~h}$ with $8 \mu \mathrm{M}$ Atiprimod, the expression of phosphorylated STAT3 protein was reduced to undetectable levels (Figure 2A, upper panel). Similarly, DNA binding of activated STAT3 was reduced by $50 \%$ after $2 \mathrm{~h}$ and completely abolished after $4 \mathrm{~h}$ (Figure 2B). Incubation of U266-B1 cells with Atiprimod at concentrations ranging from 1 to $8 \mu \mathrm{M}$ for $1 \mathrm{~h}$ significantly downregulated STAT3 phosphorylation (Figure 2A, lower panel), suggesting that Atiprimod inhibits the Janus tyrosine kinase (JAK)-STAT signalling pathway in myeloma cells.

Given that Atiprimod inhibited NF- $\kappa$ B activity at a concentration of $10 \mu \mathrm{M}$ but not $5 \mu \mathrm{M}$, and exposure to Atiprimod at a lower concentration $(4 \mu \mathrm{M})$ for $1 \mathrm{~h}$ downregulated STAT3 phosphorylation (Figure 2A), we conclude that Atiprimod inhibited STAT3 phosphorylation directly and that this effect was not mediated through the inhibition of NF- $\kappa \mathrm{B}$.

We then tested the effects of Atiprimod on the IL-6-responsive myeloma cell line MM-1 (Deane and Norton, 1990). As expected, we found that IL-6 induced STAT3 phosphorylation in a dosedependent manner at concentrations ranging from 0.5 to $2 \mathrm{ng} \mathrm{ml}^{-1}$. However, this effect was significantly attenuated by Atiprimod (Figure 2C). These results confirm our previous data showing that that Atiprimod inhibits STAT3 phosphorylation.

\section{Atiprimod inhibits myeloma cell proliferation}

As the activation of STAT3 stimulates MM cell proliferation (Kaptein et al, 1996; Bharti et al, 2004), we sought to determine whether Atiprimod would reduce the proliferation and metabolic 

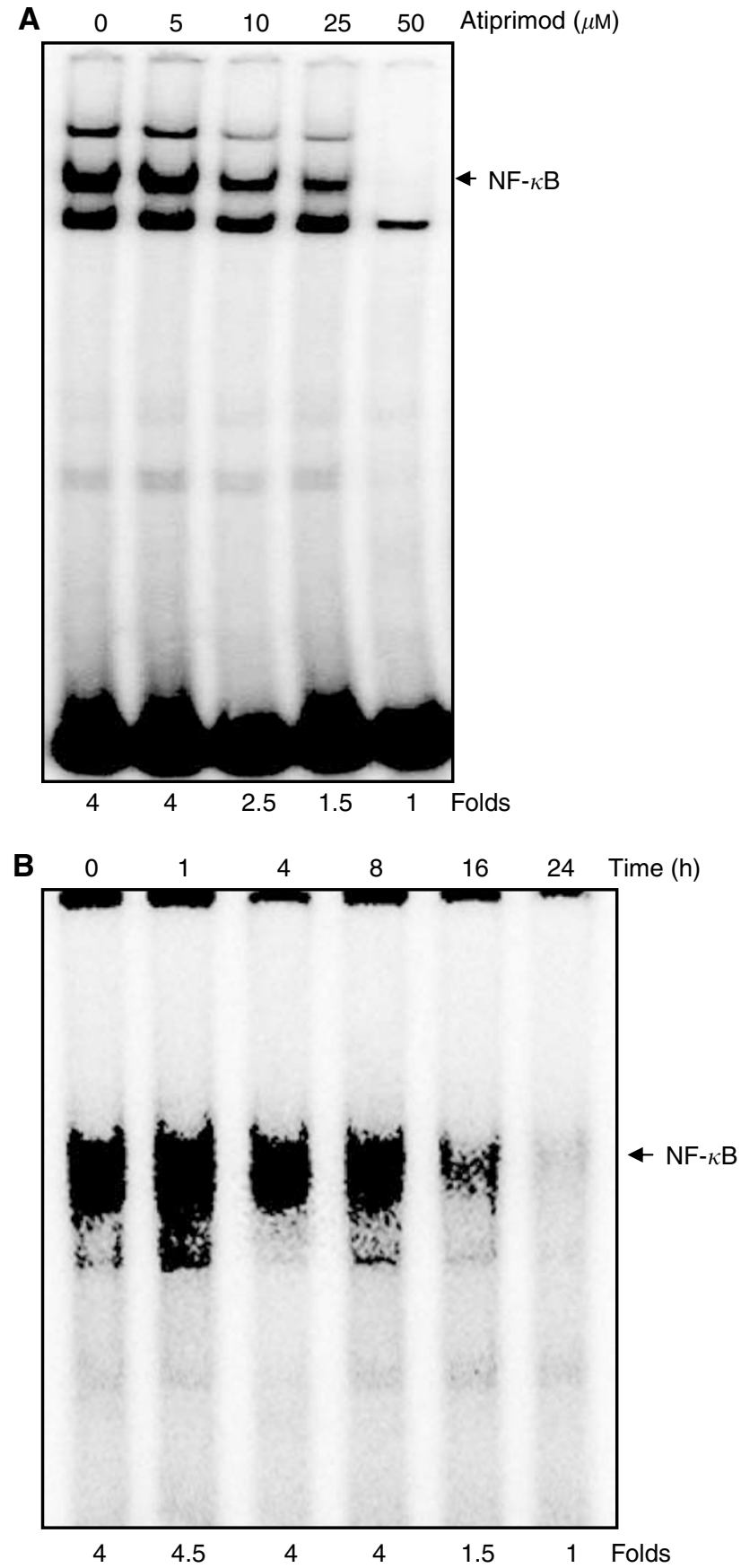

Figure I Effect of Atiprimod on activation of NF- $\kappa$ B. U266-BI cells were incubated for $4 \mathrm{~h}$ with increasing concentrations of Atiprimod $(\mathbf{A})$ and with $8 \mu \mathrm{M}$ of Atiprimod for I, 4, 8, 16, and $24 \mathrm{~h}$ (B). Nuclear extracts were prepared, and NF- $\kappa \mathrm{B}$ activity was analysed by EMSA, as described in Materials and Methods.

activity of different MM cell lines. We found that Atiprimod inhibited U266-B1, OCI-MY5, MM-1, and MM-1R myeloma lines in a dose- and time-dependent fashion (Figure 3A). Atiprimod at a concentration of $5 \mu \mathrm{M}$ inhibited MM-1 and MM-1R cell growth by 96.7 and $72 \%$, respectively, and Atiprimod at a concentration of $8 \mu \mathrm{M}$ inhibited U266B-1 and OCI-MY5 cells by 99 and $91.5 \%$, respectively. Atiprimod did not affect the growth of RPMI-8266 myeloma cells.
The antiproliferative effect of atiprimod is not reversed by IL-6, vascular endothelial growth factor (VEGF), or BM stroma

We next asked whether IL-6, VEGF, or BM stroma, previously shown to promote growth and survival of MM cells (Chauhan et al, 1996; Podar et al, 2001; Iwasaki et al, 2002; Menu et al, 2004), would reverse the inhibitory effect of Atiprimod. To investigate this, we plated the BM stroma cell line KM102 in 96-well flatbottomed plates. After they reached confluence, we added $5 \times 10^{4}$ U266-B1 cells to the wells together with fresh RPMI-1640 supplemented with $10 \%$ FCS with or without either IL-6 or VEGF at $5 \mathrm{ng} \mathrm{ml}^{-1}$; the cells were then cultured in the presence or absence of Atiprimod for $72 \mathrm{~h}$. After incubation, U266-B1 cells were harvested and assayed using MTT as described above. As was the case in our previous experiments, Atiprimod inhibited U266$\mathrm{B} 1$ cells in a dose-dependent fashion (Figure $3 \mathrm{~B}$ and $\mathrm{C}$ ). Although Atiprimod suppressed IL-6 production and either reduced or did not affect soluble IL-6R levels (Tables 2 and 3), neither IL-6 nor VEGF at a concentration of $5 \mathrm{ng} \mathrm{ml}^{-1}$ attenuated the inhibitory effect of Atiprimod. Coculture of U266-B1 cells with KM102 stroma cells only partially reversed the inhibitory effect of Atiprimod; the addition of either IL-6 or VEGF to U266-B1 cells cocultured with KM102 cells did not affect Atiprimod's inhibitory effect (Figure 3B and C). Similar results were obtained with $10 \mathrm{ng} \mathrm{ml}^{-1}$ of IL- 6 and VEGF (data not shown).

\section{Atiprimod induces accumulation of MM cells in the sub- $G_{0} / G_{1}$ phase of the cell cycle}

As Atiprimod blocked STAT3 phosphorylation and inhibited MM cell proliferation, we asked how this drug affects the progression of U266-B1 cells through the cell cycle. To answer this question, we incubated U266-B1 cells with $6 \mu \mathrm{m}$ Atiprimod and performed a cell cycle analysis using flow cytometry. We found that Atiprimod induced a sub- $\mathrm{G}_{0} / \mathrm{G}_{1}$ accumulation with 44.3 and $52.2 \%$ of the cells accumulating in sub- $\mathrm{G}_{0}$ phase at 60 and $90 \mathrm{~min}$, respectively (Figure 4).

\section{Atiprimod downregulates $\mathrm{Bcl}-2, \mathrm{Bcl}-\mathrm{X}_{\mathrm{L}}$, and $\mathrm{Mcl}-1$ protein levels}

The Bcl-2 protein family is involved in the regulation of apoptotic cell death. Recent studies showed that several myloma cell lines express Bcl-2 protein at high levels (Pettersson et al, 1992), providing MM cells with survival advantage (Feinman et al, 1999), and that activation of STAT3 upregulates the expression of Bcl- $\mathrm{X}_{\mathrm{L}}$ (Catlett-Falcone et al, 1999). Furthermore, IL-6 was shown to upregulate Mcl-1 levels in MM cells through activation of the JAKSTAT pathway (Puthier et al, 1999). Therefore, we asked whether Atiprimod would affect the levels of Bcl-2, Bcl- $\mathrm{X}_{\mathrm{L}}$, and Bcl-1. As shown in Figure 5, we found that Atiprimod reduced the levels of these proteins in U266-B1 cells.

\section{Atiprimod induces apoptotic cell death}

As Atiprimod blocked STAT3 activation, inhibited MM cell proliferation, induced cell cycle arrest in U266-B1 cells at the $\mathrm{G}_{0} / \mathrm{G}_{1}$ phase, and reduced the levels of Bcl-2, Bcl- $\mathrm{X}_{\mathrm{L}}$, and Mcl-1, we hypothesised that Atiprimod induces apoptotic cell death. To test this hypothesis, we incubated U266-B1 cells at the peak of their growth for $4 \mathrm{~h}$ in the presence or absence of 2,4 , or $8 \mu \mathrm{M}$ Atiprimod. Using annexinV-CY5, we demonstrated that Atiprimod induced apoptosis in U266-B1 cells in a dose-dependent fashion. The percentage of cells undergoing apoptotic cell death increased from 10.89 to $46.27 \%$ after exposure to $8 \mu \mathrm{M}$ Atiprimod (Figure 6A). Interestingly, U266-B1 cells accumulated in sub- $\mathrm{G}_{0}$ phase of the cell cycle after $60(44.3 \%)$ and $90(52.2 \%) \mathrm{min}$ of 

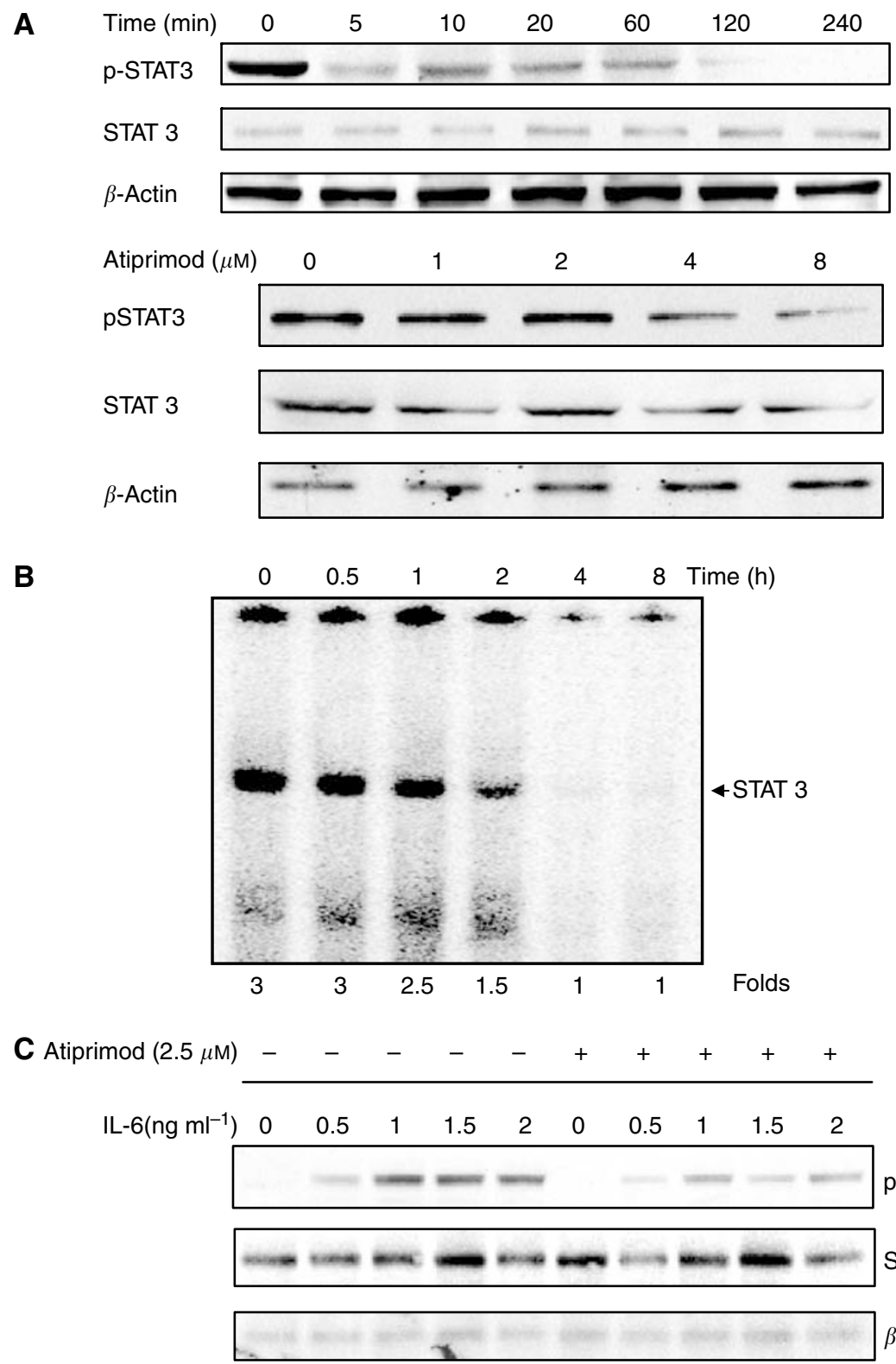

$\beta$-Actin

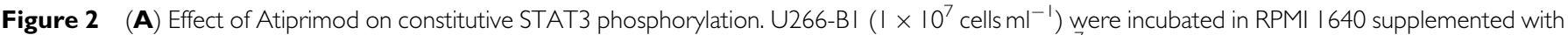
$10 \%$ FCS with or without $8 \mu \mathrm{M}$ Atiprimod for 5-240 min (upper panel). In a separate experiment, I $\times 10^{7} \mathrm{U} 266-\mathrm{B} \mid$ cells were incubated with or without increasing concentrations of Atiprimod for I h(lower panel). Signal transducer and activator of transcription (STAT) 3 and phosphorylated (p) STAT3 and were detected by Western immunoblotting as described in Materials and Methods. Equal loading of protein was confirmed by using anti- $\beta$-actin antibodies. (B) Effect of Atiprimod on binding of DNA with activated STAT3. U266-BI cells were incubated with $8 \mu \mathrm{M}$ Atiprimod for 0.5, I, 2, 4, and 6h. Nuclear extracts were labelled with hSIE probe and STAT3-DNA binding was analysed by EMSA, as described in Materials and Methods. (C) Effect of Atiprimod on

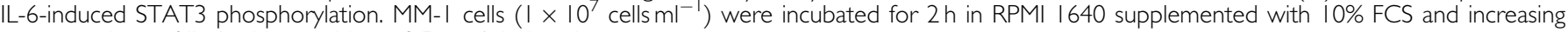
concentrations of IL-6 with or without $2.5 \mu \mathrm{M}$ Atiprimod.

exposure to $6 \mu \mathrm{m}$ Atiprimod (Figure 4). Thus, either not all cells accumulated in sub- $\mathrm{G}_{0}$ phase undergo apoptosis or different apoptosis assays yield dissimilar results (Sailer et al, 1988; Clarke et al, 2000).

\section{Atiprimod induces apoptosis by activating the caspase pathway}

To validate these findings, we incubated U266-B1 cells with or without $8 \mu \mathrm{M}$ Atiprimod in the presence or absence of $50 \mu \mathrm{M}$ of the caspase inhibitor Ac-DEVD-CHO and used the TUNEL assay to detect apoptotic cells. As shown in Figure $6 \mathrm{~B}$, we found that
Atiprimod induced apoptotic cell death in $90 \%$ of U266-B1 cells, and the addition of c-DEVD-CHO blocked Atiprimod-induced apoptosis.

Apoptosis is executed through the activation of a family of cystein proteases named caspases, which are synthesised as latent intracellular proenzymes. Cleavage of the procaspase forms converts them into biologically active caspases (Strasser et al, 2000; Orlowski and Baldwin, 2002). We chose to study the effect of Atiprimod on the activation of caspase 3, the downstream 'executioner' caspase (Nicholson, 1999) in U266-B1 cells. As shown in the Western immunoblot in the upper panel of Figure $6 \mathrm{C}$, Atiprimod induced procaspase 3 cleavage in a time-dependent 
A
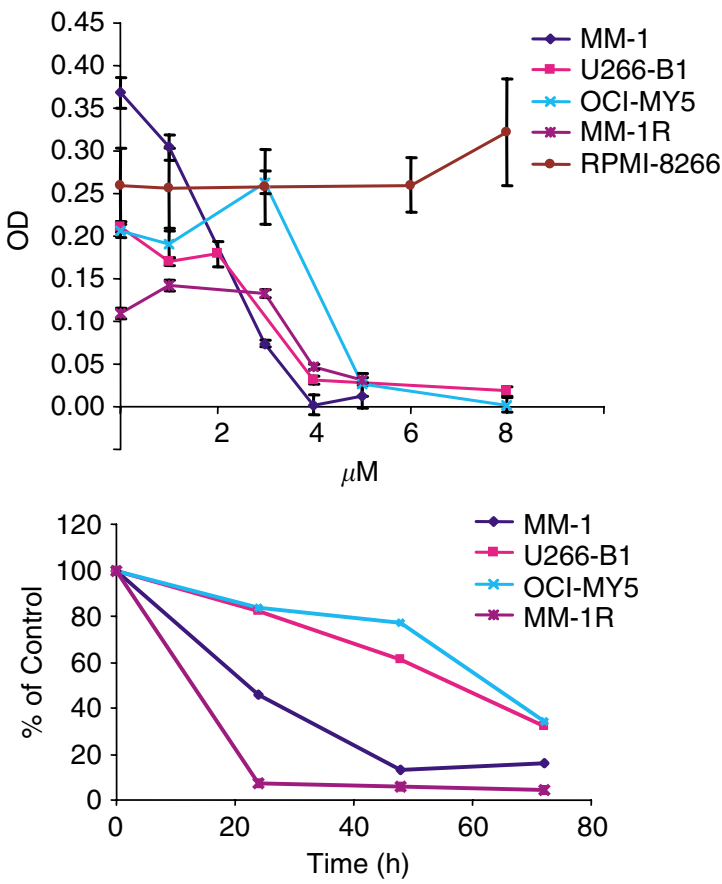

B
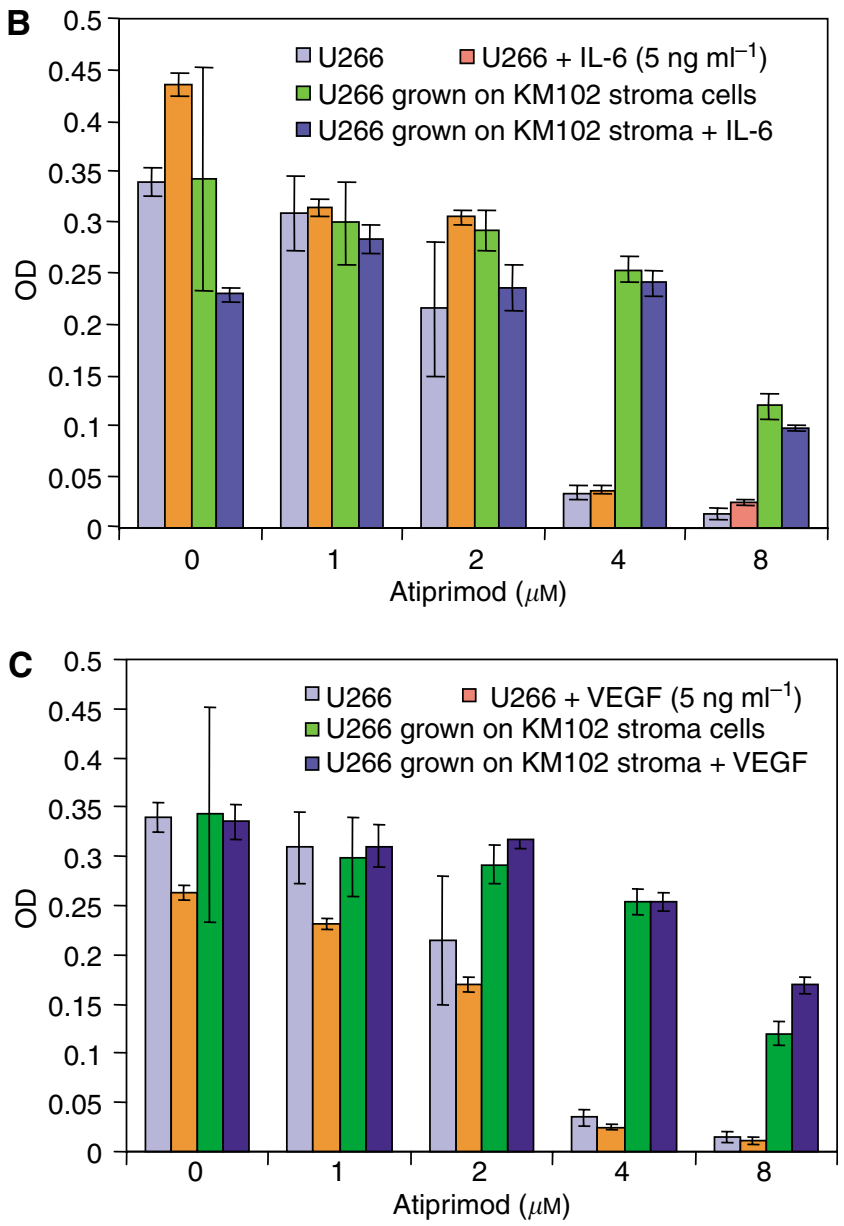

Figure 3 (A) Effect of Atiprimod on MM cell lines. Upper panel: MM-I, U266-BI, OCI-M5, MM-IR, and RPMI-8266 $\left(5 \times 10^{4}\right)$ cells were incubated in RPMI I 640 supplemented with I0\% FCS with or without increasing concentrations of Atiprimod for $72 \mathrm{~h}$. Cells were harvested and their metabolic activity and viability were determined using the MTT assay. Data are presented as the mean \pm standard deviation of optical density (OD) measurements of six wells. Lower panel: MM-I, U266-BI, OCl-M5, and MM-IR cells $\left(5 \times 10^{4}\right)$ were incubated with $4 \mu \mathrm{M}$ Atiprimod for 24, 48, and $72 \mathrm{~h}$. Cells were harvested and their metabolic activity and viability were determined using the MTT assay. Data are presented as a percent of OD of cells cultured without Atiprimod at the same time point (control). (B, C) Effect of IL-6, VEGF, and BM stroma on Atiprimod-induced inhibition of U266-BI cells. These cells were cultured alone or with adherent KMIO2 stroma cells, with or without either IL-6 (B) or VEGF (C) at $5 \mathrm{ng} \mathrm{ml}{ }^{-1}$, and in the presence of increasing concentrations of Atiprimod. After $72 \mathrm{~h}, \mathrm{U} 266-\mathrm{BI}$ cells were harvested and analysed using the MTT assay. The data are presented as the mean \pm standard deviation of OD measurements of five wells.

Table 3 Soluble interleukin-6 receptor (IL-6R) supernatant levels $\left(\mathrm{pg} \mathrm{ml} l^{-1}\right)$

\begin{tabular}{|c|c|c|c|c|c|c|}
\hline & \multirow[b]{2}{*}{-} & \multirow[b]{2}{*}{ Atiprimod } & \multicolumn{2}{|c|}{ +Normal stroma } & \multicolumn{2}{|c|}{ +KMIO2 } \\
\hline & & & - & Atiprimod & - & Atiprimod \\
\hline Normal stroma & 650 & 467 & & & & \\
\hline KMIO2 & 521 & 485 & & & & \\
\hline MMI & 0 & 0 & 573 & 594 & 583 & 566 \\
\hline MMIR & 0 & 0 & 572 & 524 & 271 & 294 \\
\hline U266-BI & 27 & 0 & 642 & 514 & 645 & 354 \\
\hline OCI-MY5 & 0 & 0 & 714 & 632 & 731 & 686 \\
\hline
\end{tabular}

Cells were incubated for $72 \mathrm{~h}$ with or without $3 \mu \mathrm{M}$ Atiprimod. The means of soluble IL-6R levels from duplicate wells are depicted.

manner, with the maximum effect achieved after $4 \mathrm{~h}$. Furthermore, incubation of U266-B1 cells for $1 \mathrm{~h}$ with Atiprimod induced a dosedependent increase in caspase 3 cleavage (Figure 6C, lower panel).

Activated caspase 3 abrogates the effect of substrates that protect cellular integrity, such as the DNA-repair enzyme
PARP (Nicholson, 1999; Kraus and Lis, 2003). When we exposed the cells to Atiprimod, we found a dose-dependent increase in cleaved PARP protein levels, with the maximum effect achieved at a concentration of $8 \mu \mathrm{m}$ (Figure $6 \mathrm{C}$, lower panel).

\section{Atiprimod inhibits MM colony-forming cell proliferation}

In light of these results, we postulated that Atiprimod would also inhibit the proliferation of primary MM cells. To investigate this, we first studied the effect of Atiprimod on fresh low-density marrow cells from three patients with MM. We incubated the cells with increasing concentrations of Atiprimod and analysed its effect using the MTT assay. As shown in Figure 7A, we found that Atiprimod suppressed the metabolic activity of MM cells in a dosedependent manner with no activity detected at $8 i \mathrm{M}$. We then asked whether Atiprimod would also inhibit myeloma colony-forming cells. We obtained BM cells from five patients with newly diagnosed, untreated MM (Table 1). As depicted in Figure 7B, we found that Atiprimod suppressed MM colony-forming cell growth in a dose-dependent manner, reaching $85 \%$ suppression at $4 \mu \mathrm{M}$ and $100 \%$ at $8 \mu \mathrm{m}$. 


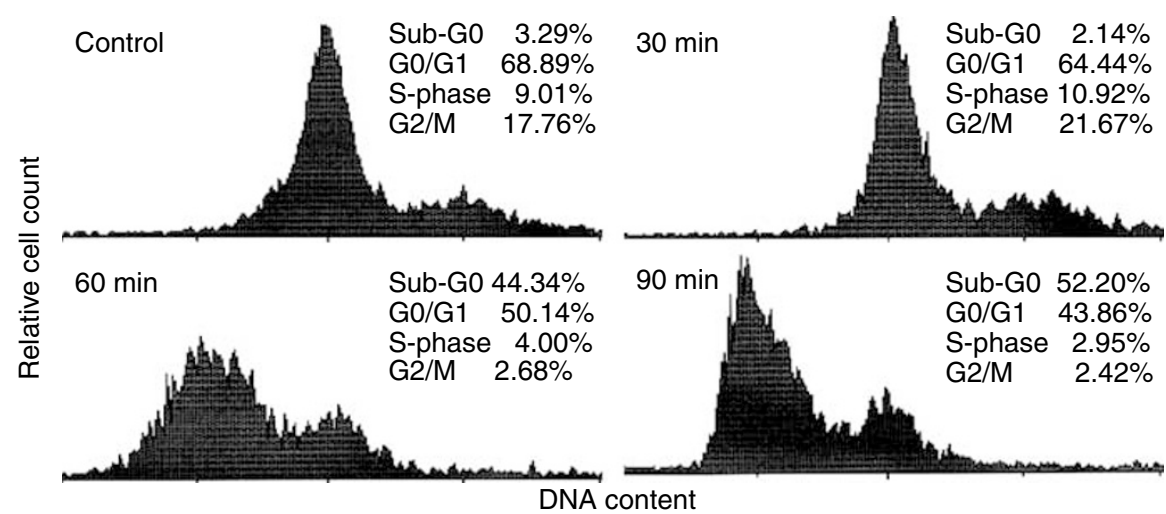

Figure 4 Effect of Atiprimod on the cell cycle status of U266-BI cells. These cells were incubated in RPMI I640 supplemented with I0\% FCS with or without $6 \mu \mathrm{M}$ Atiprimod, and cell cycle analysis was performed as described above. The percentages of cells in sub- $G_{0}, G_{0} / G_{1}, S$, and $G 2 M$ phases of the cell cycle are given.

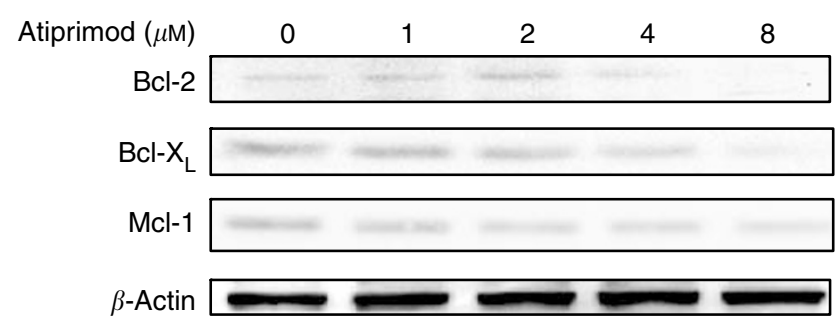

Figure 5 Effect of Atiprimod on $\mathrm{BCl}-2, \mathrm{BCl}-\mathrm{X}_{\mathrm{L}}$, and $\mathrm{Mcl}-\mathrm{I}$ protein levels. U266-BI cells were incubated for $2 \mathrm{~h}$ with Atiprimod at increasing concentrations. The levels of $\mathrm{BCl}-2, \mathrm{Bcl}-\mathrm{X}_{\mathrm{L}}$, and $\mathrm{Mcl}-\mathrm{I}$ were detected by Western immunoblotting. The results shown here demonstrate a dosedependent decrease in the levels of Bcl-2, Bcl- $X_{L}$, and Mcl- I.

Multiple myeloma colonies were identified by their morphological characteristics, as depicted in the upper panel of Figure 7C. To verify that the MM colony-forming cells originated from the neoplastic clone, single colonies were microaspirated at random, and the rearranged IgH gene in DNA from the original BM sample and from individual MM colonies was amplified via PCR using primers chosen from the first framework region of the coding strand of representative germline $\mathrm{V}_{\mathrm{H}}$ family members and a $\mathrm{J}_{\mathrm{H}}$ consensus primer. As shown at the bottom of Figure $7 \mathrm{C}$, all analysed colonies showed an IgH gene rearrangement identical to that of the diagnostic marrow cells. Sequence analysis of colonyderived DNA showed a $90 \%$ homology with the original MM cell DNA, confirming the neoplastic clonal origin of the colonyforming cells.

\section{DISCUSSION}

Several growth factors and cytokines stimulate MM cell proliferation by activating various signalling pathways (Zhang et al, 2003; Giuliani et al, 2004). Of those molecules, IL-6 has been studied extensively, and its pathophysiologic effects in MM have been well characterised (Klein et al, 1995; Chauhan et al, 1996). Since Atiprimod downregulates serum IL-6 levels (Bradbeer et al, 1996), we tested Atiprimod's effect on U266-B1 cells, known to constitutively produce IL-6 (Catlett-Falcone et al, 1999), and found that Atiprimod suppressed IL-6 production in a time-dependent manner.

Since IL-6 expression is regulated by NF- $\kappa$ B (Shimizu et al, 1990 ), we investigated whether Atiprimod inhibits NF- $\kappa$ B activity. The NF- $\kappa$ B transcription factor family is an important modulator of cellular proliferation, suppression of apoptosis, enhancement of tumour cell invasiveness, and induction of angiogenesis (Orlowski and Baldwin, 2002). The antitumour activity of the proteasome inhibitor bortezomab in $\mathrm{MM}$ is thought to be mediated through the inhibition of NF- $\kappa \mathrm{B}$ (Voorhees et al, 2003). We recently found that fresh BM cells obtained from MM patients express constitutively active NF- $\kappa \mathrm{B}$ and STAT3 (Bharti et al, 2004). Furthermore, MM patients' myeloma cells constitutively produce IL-6 (CatlettFalcone et al, 1999; Bharti et al, 2003). Thus, it is possible that constitutively activated NF- $\kappa \mathrm{B}$ induces the production of IL-6, which in turn activates STAT3 (Kaptein et al, 1996; Chatterjee et al, 2002) and MM cell proliferation. Therefore, we wondered whether Atiprimod inhibits NF- $\kappa$ B activity and, by doing so, downregulates constitutive production of IL-6. Using U266-B1 cells, which express constitutively active NF- $\kappa \mathrm{B}$ and STAT3 (Bharti et al, 2004) and produce IL-6, we found that Atiprimod inhibited NF- $\kappa$ B activation.

Since Atiprimod inhibited NF- $\kappa \mathrm{B}$ and IL- 6 production, we wondered whether Atiprimod also downregulated IL-6 signalling. Using U266-B1 cells, we found that Atiprimod inhibited STAT3 phosphorylation after a shorter incubation and at concentrations lower than those required for the inhibition of NF- $\kappa \mathrm{B}$. As these results suggested that Atiprimod directly inhibited STAT3 phosphorylation, we used MM-1 cells in which the JAK-STAT pathway is activated upon exposure to exogenous IL-6 (Chatterjee et al, 2002). As in our previous experiments with U266-B1 cells, we found that Atiprimod inhibited the IL-6-induced STAT3 phosphorylation in MM-1 cells in a time- and dose-dependent manner. These results suggest that Atiprimod suppresses STAT3 phosphorylation directly, and that this effect is not dependent on the inhibition of NF- $\kappa \mathrm{B}$. Nevertheless, the ability of Atiprimod to inhibit NF- $\kappa \mathrm{B}$, a proven target in myeloma treatment, suggests that Atiprimod might also inhibit myeloma cells through that mechanism, provided that higher concentrations of this drug are used.

As Atiprimod blocked STAT3 phosphorylation and thus the JAK-STAT pathway, we tested the effect of Atiprimod on MM cell proliferation. As expected, Atiprimod inhibited several myeloma cell lines. Specifically, Atiprimod induced accumulation of myeloma cells at the sub- $G_{0} / G_{1}$ phase of the cell cycle. Atiprimod inhibited MM-1 and the dexamethasone-resistant MM-1R cells in the absence of exogenous IL-6. Although small amounts of IL-6 present in FCS could have stimulated the JAK-STAT pathway in these cells, Atiprimod might have blocked other signalling pathways involved in stimulating the proliferation of MM-1 and OCI-MY5 cells.

We then asked whether Atiprimod could inhibit the proliferation of primary MM cells. Using the myeloma colony culture assay, we found that Atiprimod suppressed the growth of 


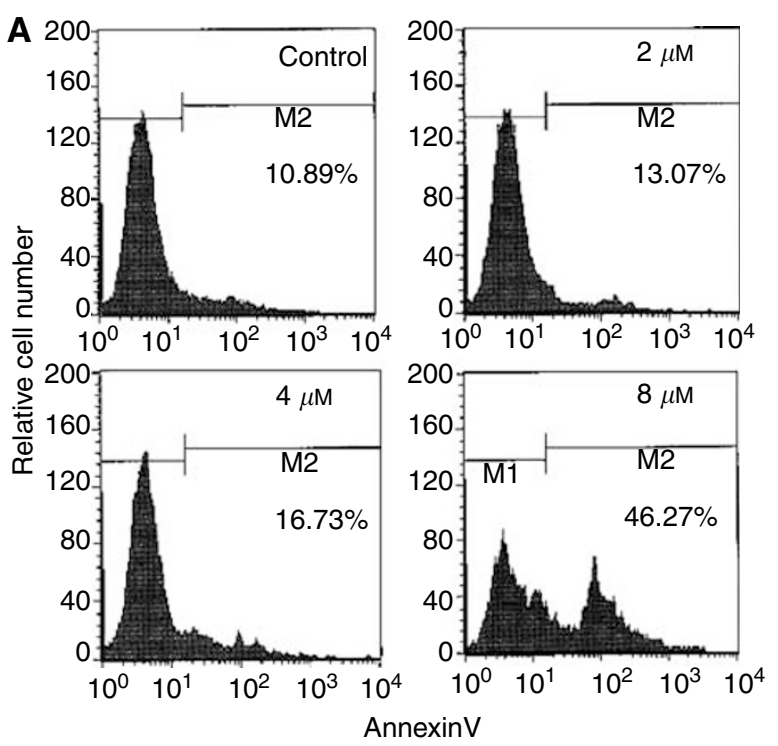

B
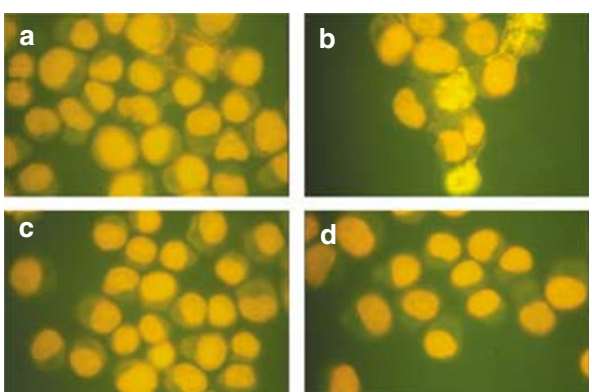

C

\begin{tabular}{|c|c|c|c|c|c|c|c|}
\hline Atiprimod $(8 \mu \mathrm{M})$ & - & + & + & + & + & + & - \\
\hline Time (min) & 0 & 5 & 10 & 20 & 120 & 240 & 240 \\
\hline
\end{tabular}

Caspase 3

$\beta$-Actin

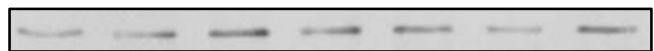

Atiprimod $(\mu \mathrm{M})$

Procasp. 3

Caspase 3

PARP (uncleaved)

PARP (cleaved)

\begin{tabular}{rrrrr}
0 & 1 & 2 & 4 & 8 \\
\hline & - & - & - & -
\end{tabular}

$\beta$-Actin

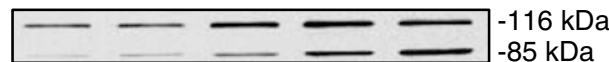

$85 \mathrm{kDa}$

Figure 6 Atiprimod induces apoptosis in myeloma cells. (A) U266-BI cells were incubated with or without 2, 4, or $8 \mu \mathrm{M}$ Atiprimod for $4 \mathrm{~h}$. The fraction of cells undergoing apoptosis was detected by annexin V-CY5. The percentages in each frame indicate the apoptotic cell fraction. (B) U266-BI cells were incubated with (b, d) or without (a, c) $8 \mu \mathrm{M}$ Atiprimod and with (c, d) or without (a, b) $50 \mu \mathrm{M}$ Ac-DEVD-CHO. After incubation, cytospun cells were stained with TUNEL. Yellow-appearing cells (apoptotic cells) were detected after exposure to Atiprimod (b). The addition of Ac-DEVD-CHO, which by itself did not affect cell morphology (c) reversed this process (d). (C) Atiprimod activates caspase 3 and cleaves PARP. U266-BI cells were incubated with $8 \mu \mathrm{M}$ Atiprimod for 0, 5, 10, 20, 120, and $240 \mathrm{~min}$ (upper panel) and Atiprimod at increasing concentrations for I h (lower panel). The levels of procaspase 3, caspase 3, and uncleaved and cleaved PARP were detected by Western immunoblotting. The results shown here demonstrate a time-dependent increase in the cleaved caspase 3 level (upper panel) and a dose-dependent increase in the cleaved caspase 3 and cleaved PARP levels (lower panel).

myeloma colony-forming cells of fresh BM samples obtained from five patients with newly diagnosed MM in a dose-dependent fashion.

As discussed above, several factors besides IL-6 contribute to myeloma cell proliferation. In particular, VEGF and marrow stroma are major players in this process (Chauhan et al, 1996; Anderson, 1999; Podar et al, 2001; Iwasaki et al, 2002).

VEGF stimulates MM cells by triggering activation of the JAKSTAT pathway (Rabinovitch et al, 1993) and exerts a proangiogenic effect that is thought to play a role in the pathogenesis of MM (Anderson, 1999). Interestingly, the levels of VEGF have been found to correlate with disease stage and progression (Iwasaki et al, 2002). Bone marrow stroma also contributes to the myelomatous process through the production of stimulating cytokines (Chauhan et al, 1996). Additionally, according to a recent study, MM cells become independent of the STAT3 pathway in the presence of BM stroma (Chatterjee et al, 2002). Therefore, we sought to determine whether IL-6, VEGF, and BM stroma interfere with the antiproliferative effect of Atiprimod. We found, however, that neither IL-6 nor VEGF negated the effect of Atiprimod, and that the BM stroma cell line KM102 only partially reversed Atiprimod's inhibitory effect.

The activation of STAT3 in myeloma cells results in the upregulation of antiapoptotic proteins of the Bcl-2 family, such as $\mathrm{Bcl}-2, \mathrm{Bcl}-\mathrm{X}_{\mathrm{L}}$, and $\mathrm{Mcl}-1$, thus providing $\mathrm{MM}$ cells with a survival advantage (Pettersson et al, 1992; Catlett-Falcone et al, 1999; Feinman et al, 1999; Puthier et al, 1999). As Atiprimod suppresses STAT3 phosphorylation, we asked how it would affect Bcl-2, Bcl- $\mathrm{X}_{\mathrm{L}}$, and Mcl-1 protein levels. We found that Atiprimod downregulated the levels of $\mathrm{Bcl}-2, \mathrm{Bcl}-\mathrm{X}_{\mathrm{L}}$, and $\mathrm{Mcl}-1$, and induced apoptotic cell death in U266-B1 myeloma cells. Atiprimod's proapoptotic effect was blocked by the caspase inhibitor AcDEVD-CHO, suggesting that apoptosis was induced through the activation of the caspase pathway. Indeed, exposure of U266-B1 myeloma cells to Atiprimod resulted in the activation of the downstream executioner caspase 3 and subsequent cleavage of the DNA repair enzyme PARP.

Taken together, our data show that Atiprimod blocks STAT3 phosphorylation and the activation of NF- $\kappa B$, inhibits cellular proliferation, causes cell cycle arrest, and induces apoptosis in MM cells. As Atiprimod was well tolerated in patients with rheumatoid arthritis, phase I studies of Atiprimod in patients with MM are warranted.

\section{ACKNOWLEDGEMENTS}

We thank David Galloway for reviewing the manuscript. 

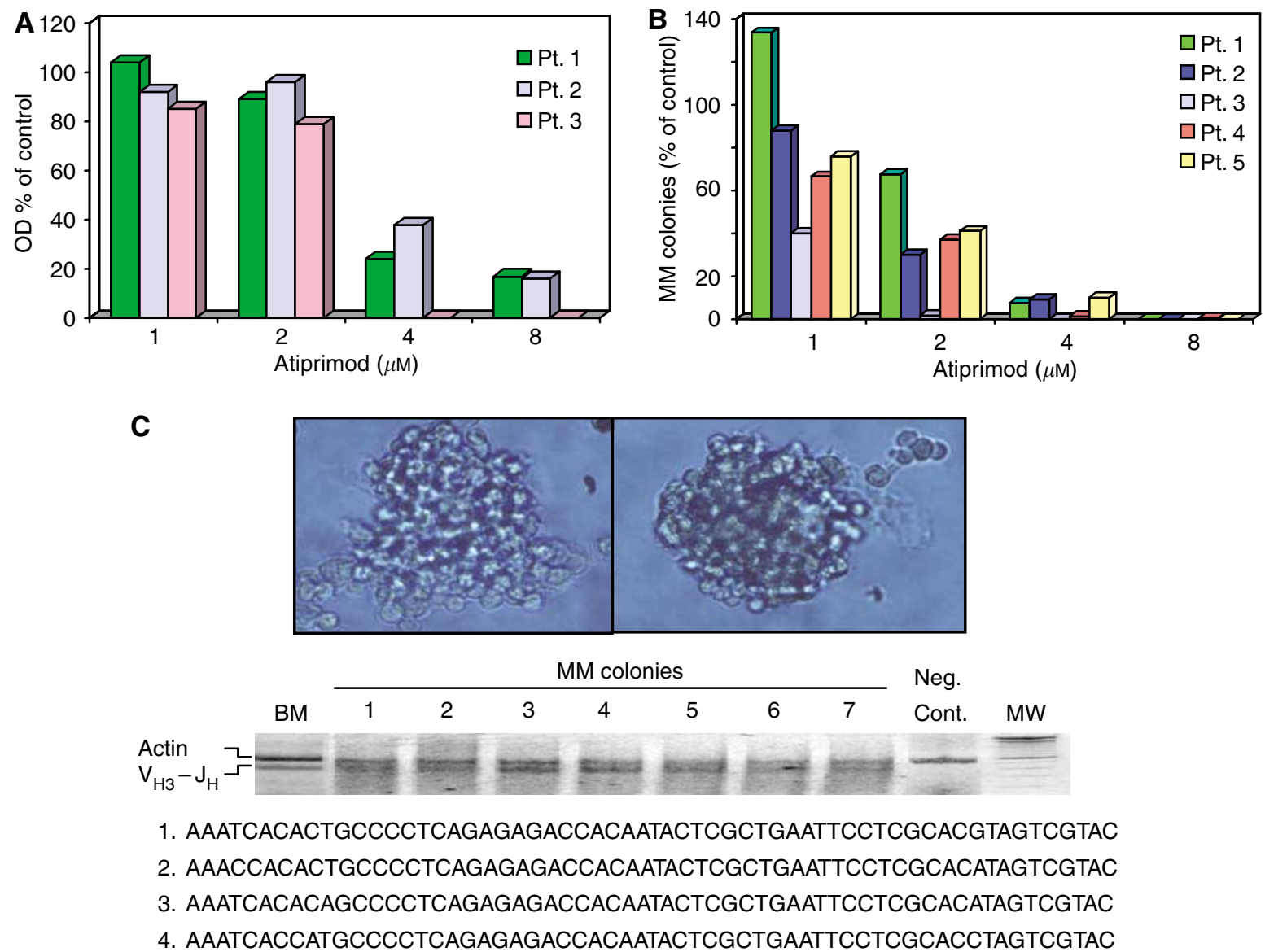

Figure 7 Atiprimod inhibits primary MM cell proliferation. (A) Low-density BM cells from three patients with MM and incubated in the presence of Atiprimod at concentrations ranging from I to $8 \mu \mathrm{M}$ and analysed using the MTT assay. (B) The effect of Atiprimod on MM colony-forming cells was studied on marrow cells from five patients with MM. After fractionation, myeloma cells were cultured in the presence of Atiprimod at concentrations ranging from I to $8 \mu \mathrm{M}$. Multiple myeloma colonies are presented as percentages of control (the mean number of colonies obtained from patients I through 5 in the absence of Atiprimod was 82, 243, 133, 179, and 467, respectively). (C) The top panel depicts two typical MM colonies. Of note are the large cells with myeloma cell morphology at the periphery of the colony. The middle panel shows the products of PCR amplification of DNA from the original marrow of patient 2 and from seven single colonies microaspirated at random using $\mathrm{V}_{\mathrm{H} 3}-J_{\mathrm{H}}$ consensus primers. The myeloid leukaemia cell line $\mathrm{OCIM} 2$ was used as a negative control (Neg. Cont.). Actin was used as an amplification control (MW denotes molecular weight). The lower panel shows the nucleotide sequences of amplified products of DNA from the D region of the diagnostic marrow (I) and of three different colonies (2-4). The middle and lower panels demonstrate that the MM colonies originated from the neoplastic clone.

\section{REFERENCES}

Albrightson-Winslow CR, Brickson B, King A, Olivera D, Short B, Saunders C, Badger AM (1990) Beneficial effects of long-term treatment with SK\&F 105685 in murine lupus nephritis. J Pharmacol Exp Ther 255: 382-387

Anderson K (1999) Advances in the biology of multiple myeloma: therapeutic applications. Semin Oncol 26: 10-22

Anderson KC (2004) Bortezomib therapy for myeloma. Curr Hematol Rep 3: 65

Badger AM, Albrightson-Winslow CR, Kupiec-Weglinski JW (1991) SK\&F 105685: a novel immunosuppressive compound with efficacy in animal models of autoimmunity and transplantation. Transplant Proc 23: $194-195$

Badger AM, Dimartino MJ, Talmadge JE, Picker DH, Schwartz DA, Dorman JW, Mirabelli CK, Hanna N (1989) Inhibition of animal models of autoimmune disease and the induction of non-specific suppressor cells by SK\&F 105685 and related azaspiranes. Int J Immunopharmacol 11: 839-846

Badger AM, King AG, Talmadge JE, Schwartz DA, Picker DH, Mirabelli CK, Hanna N (1990a) Induction of non-specific suppressor cells in normal Lewis rats by a novel azaspirane SK\&F 105685. J Autoimmun 3: $485-500$
Badger AM, Schwartz DA, Picker DH, Dorman JW, Bradley FC, Cheeseman EN, DiMartino MJ, Hanna N, Mirabelli CK (1990b) Antiarthritic and suppressor cell inducing activity of azaspiranes: structure-function relationships of a novel class of immunomodulatory agents. J Med Chem 33: $2963-2970$

Bharti AC, Donato N, Singh S, Aggarwal BB (2003) Curcumin (diferuloylmethane) down-regulates the constitutive activation of nuclear factor-kappa B and IkappaBalpha kinase in human multiple myeloma cells, leading to suppression of proliferation and induction of apoptosis. Blood 101: $1053-1062$

Bharti AC, Shishodia S, Reuben JM, Weber D, Alexanian R, Raj-Vadhan S, Estrov Z, Talpaz M, Aggarwal BB (2004) Nuclear factor-kappaB and STAT3 are constitutively active in CD138+ cells derived from multiple myeloma patients, and suppression of these transcription factors leads to apoptosis. Blood 103: 3175-3184

Bradbeer JN, Kapadia RD, Sarkar SK, Zhao H, Stroup GB, Swift BA, Rieman DJ, Badger AM (1996) Disease-modifying activity of SK\&F 106615 in rat adjuvant-induced arthritis. Multiparameter analysis of disease magnetic resonance imaging and bone mineral density measurements. Arthritis Rheum 39: 504-514 
Catlett-Falcone R, Landowski TH, Oshiro MM, Turkson J, Levitzki A, Savino R, Ciliberto G, Moscinski L, Fernandez-Luna JL, Nunez G, Dalton WS, Jove R (1999) Constitutive activation of Stat3 signaling confers resistance to apoptosis in human U266 myeloma cells. Immunity 10: $105-115$

Chatterjee M, Honemann D, Lentzsch S, Bommert K, Sers C, Herrmann P, Mathas S, Dorken B, Bargou RC (2002) In the presence of bone marrow stromal cells human multiple myeloma cells become independent of the IL-6/gp130/STAT3 pathway. Blood 100: 3311-3318

Chaturvedi MM, Mukhopadhyay A, Aggarwal BB (2000) Assay for redoxsensitive transcription factor. Methods Enzymol 319: 585-602

Chauhan D, Uchiyama H, Akbarali Y, Urashima M, Yamamoto K, Libermann TA, Anderson KC (1996) Multiple myeloma cell adhesioninduced interleukin- 6 expression in bone marrow stromal cells involves activation of NF-kappa B. Blood 87: 1104-1112

Clarke RG, Lund EK, Johnson IT, Pinder AC (2000) Apoptosis can be detected in attached colonic adenocarcinoma HT29 cells using Annexin V binding, but not TUNEL assay or sub-G0 DNA content. Cytometry 39: $141-150$

Cote S, Simard C, Lemieux R (2002) Regulation of growth-related genes by interleukin-6 in murine myeloma cells. 20(3): 113-120

Deane M, Norton JD (1990) Immunoglobulin heavy chain variable region family usage is independent of tumor cell phenotype in human B lineage leukemias. Eur J Immunol 20: 2209-2217

Dimopoulos MA, Anagnostopoulos A, Weber D (2003) Treatment of plasma cell dyscrasias with thalidomide and its derivatives. J Clin Oncol 21: $4444-4454$

Estrov Z, Manna SK, Harris D, Van Q, Estey EH, Kantarjian HM, Talpaz M, Aggarwal BB (1999) Phenylarsine oxide blocks interleukin-1beta-induced activation of the nuclear transcription factor NF-kappaB, inhibits proliferation, and induces apoptosis of acute myelogenous leukemia cells. Blood 94: 2844-2853

Estrov Z, Ouspenskaia MV, Felix EA, McClain KL, Lee MS, Harris D, Pinkel DP, Zipf TF (1994) Persistence of self-renewing leukemia cell progenitor during remission in children with B-precursor acute lymphoblastic leukemia. Leukemia 8: 46-52

Fan PY, Albrightson CR, Howell DN, Best C, Badger AM, Coffman TM (1993) The azaspirane SKF 105685 ameliorates renal allograft rejection in rats. J Am Soc Nephrol 3: $1680-1685$

Feinman R, Koury J, Thames M, Barlogie B, Epstein J, Siegel DS (1999) Role of NF-kappaB in the rescue of multiple myeloma cells from glucocorticoid-induced apoptosis by bcl-2. Blood 93: 3044-3052

Gershoni JM, Palade GE (1983) Protein blotting: principles and applications. Anal Biochem 131: 1-15

Giuliani N, Lunghi P, Morandi F, Colla S, Bonomini S, Hojden M, Rizzoli V, Bonati A (2004) Downmodulation of ERK protein kinase activity inhibits VEGF secretion by human myeloma cells and myeloma-induced angiogenesis. Leukemia 18: 628-635

Harigaya K, Handa H (1985) Generation of functional clonal cell lines from human bone marrow stroma. Proc Natl Acad Sci USA 82: 3477-3480

Hirano T, Ishihara K, Hibi M (2000) Roles of STAT3 in mediating the cell growth, differentiation and survival signals relayed through the IL-6 family of cytokine receptors. Oncogene 19: 2548-2556

Iwasaki T, Hamano T, Ogata A, Hashimoto N, Kitano M, Kakishita E (2002) Clinical significance of vascular endothelial growth factor and hepatocyte growth factor in multiple myeloma. Br J Haematol 116: 796-802

Jemal A, Murray T, Samuels A, Ghafoor A, Ward E, Thun MJ (2003) Cancer statistics, 2003. CA Cancer J Clin 53: 5-26

Kaptein A, Paillard V, Saunders M (1996) Dominant negative stat3 mutant inhibits interleukin-6-induced Jak-STAT signal transduction. J Biol Chem 271: $5961-5964$

Kawano M, Hirano T, Matsuda T, Taga T, Horii Y, Iwato K, Asaoku H, Tang $\mathrm{B}$, Tanabe O, Tanaka H (1988) Autocrine generation and requirement of BSF-2/IL-6 for human multiple myelomas. Nature 332: 83-85

King AG, Olivera D, Talmadge JE, Badger AM (1991) Induction of non-specific suppressor cells and myeloregulatory effects of an immunomodulatory azaspirane, SK\&F 105685. Int J Immunopharmacol 13: $91-100$

Klein B, Zhang XG, Jourdan M, Portier M, Bataille R (1990) Interleukin-6 is a major myeloma cell growth in vitro and in vivo especially in patients with terminal disease. Curr Top Microbiol Immunol 166: 23-31

Klein B, Zhang XG, Lu ZY, Bataille R (1995) Interleukin-6 in human multiple myeloma. Blood 85: 863-872

Kraus WL, Lis JT (2003) PARP goes transcription. Cell 113: 677-683
Laemmli UK (1970) Cleavage of structural proteins during the assembly of the head of bacteriophage T4. Nature 227: 680-685

Lichtenstein A, Tu Y, Fady C, Vescio R, Berenson J (1995) Interleukin-6 inhibits apoptosis of malignant plasma cells. Cell Immunol 162: 248-255

Menu E, Kooijman R, Van Valckenborgh E, Asosingh K, Bakkus M, Van Camp B, Vanderkerken K (2004) Specific roles for the PI3K and the MEK-ERK pathway in IGF-1-stimulated chemotaxis, VEGF secretion and proliferation of multiple myeloma cells: study in the 5T33MM model. $\mathrm{Br}$ Cancer 90: 1076-1083

Millar BC, Bell JB, Lakhani A, Ayliffe MJ, Selby PJ, McElwain TJ (1988) A simple method for culturing myeloma cells from human bone marrow aspirates and peripheral blood in vitro. Br J Haematol 69: 197-203

Ni H, Ergin M, Huang Q, Qin J-Z, Amin HM, Martinez RL, Saseed S, Barton $\mathrm{K}$, Alkan S (2001) Analysis of expression of nuclear factor $\kappa \mathrm{B}$ (NF- $\kappa \mathrm{B})$ in multiple myeloma: downregulation of NF- $\kappa \mathrm{B}$ induced apoptosis. $\mathrm{Br}$ Haematol 115: 279-286

Nicholson DW (1999) Caspase structure, proteolytic substrates, and function during apoptotic cell death. Cell Death Differ 6: 1028-1042

Orlowski RZ, Baldwin Jr AS (2002) NF-kappaB as a therapeutic target in cancer. Trends Mol Med 8: 385-389

Pettersson M, Jernberg-Wiklund H, Larsson LG, Sundstrom C, Givol I, Tsujimoto Y, Nilsson K (1992) Expression of the bcl-2 gene in human multiple myeloma cell lines and normal plasma cells. Blood 79: 495-502

Podar K, Tai YT, Davies FE, Lentzsch S, Sattler M, Hideshima T, Lin BK, Gupta D, Shima Y, Chauhan D, Mitsiades C, Raje N, Richardson P, Anderson KC (2001) Vascular endothelial growth factor triggers signaling cascades mediating multiple myeloma cell growth and migration. Blood 98: 428-435

Puthier D, Bataille R, Amiot M (1999) IL-6 upregulates mcl-1 in human myeloma cells through JAK/STAT rather than ras/MAP kinase pathway. Eur J Immunol 29: 3945-3950

Rabinovitch A, Suarez WL, Qin HY, Power RF, Badger AM (1993) Prevention of diabetes and induction of non-specific suppressor cell activity in the $\mathrm{BB}$ rat by an immunomodulatory azaspirane, SK\&F 106610. J Autoimmun 6: 39-49

Rhodes EG, Olive C, Flynn MP (1990) A serum-free culture method for myeloma progenitors in vitro: proliferative and immunophenotypic characteristics. Exp Hematol 18: 79-83

Sailer BL, Valdez JD, Steinkamp JA, Crissman HA (1988) Apoptosis induced with different cycle-perturbing agents produces differentia changes in the fluorescence lifetime of DNA-bound ethidium bromide. Cytomentry 31: 208-216

Schmidbauer G, Hancock WW, Badger AM, Kupiec-Weglinski JW (1993) Induction of nonspecific X-irradiation-resistant suppressor cell activity in vivo and prolongation of vascularized allograft survival by SK\&F 105685, a novel immunomodulatory azaspirane. Transplantation 55: $1236-1243$

Shimizu H, Mitomo K, Watanabe T, Okamoto S, Yamamoto K (1990) Involvement of a NF-kappa B-like transcription factor in the activation of the interleukin- 6 gene by inflammatory lymphokines. Mol Cell Biol 10: $561-568$

Strasser A, O'Connor L, Dixit VM (2000) Apoptosis signaling. Annu Rev Biochem 69: 217-245

Szczepek AJ, Belch AR, Pilarski LM (2001) Expression of IL-6 and IL-6 receptors by circulating clonotypic B cells in multiple myeloma: potential for autocrine and paracrine networks. Exp Hematol 29: 1076-1081

Thornberry NA, Peterson EP, Zhao JJ, Howard AD, Griffin PR, Chapman KT (1994) Inactivation of interleukin-1 beta converting enzyme by peptide (acyloxy)methyl ketones. Biochemistry 33: 3934-3940

Towbin H, Staehelin T, Gordon J (1979) Electrophoretic transfer of proteins from polyacrylamide gels to nitrocellulose sheets: procedure and some applications. Proc Natl Acad Sci USA 76: 4350-4354

Vermes I, Haanen C, Steffens-Nakken H, Reutelingsperger C (1995) A novel assay for apoptosis. Flow cytometric detection of phosphatidylserine expression on early apoptotic cells using fluorescein labelled Annexin V. J Immunol Methods 184: 39-51

Voorhees PM, Dees EC, O'Neil B, Orlowski RZ (2003) The proteasome as a target for cancer therapy. Clin Cancer Res 9: 6316-6325

Yu CL, Meyr DJ, Campbell GS, Larner AC, Carter-Su C, Schwartz J, Jove R (1995) Enhanced DNA-binding activity of a Stat3-related protein in cells transformed by the Src oncoprotein. Science 269: 81-83

Zhang J, Choi Y, Mavromatis B, Lichtenstein A, Li W (2003) Preferential killing of PTEN-null myelomas by PI3K inhibitors through Akt pathway. Oncogene 22: 6289-6295 